\title{
STRUCTURAL-FUNCTIONAL MECHANISM OF ORGANIZATION OF ELIMINATION OF CONSEQUENCES OF EMERGENCY CONDITIONS OF MEDICAL AND BIOLOGICAL CHARACTER
}

\author{
Bogdan Chernenko ${ }^{1}$ \\ ${ }^{I}$ Graduate student, Institute of Public Administration and Research in Civil Defense, Kyiv, Ukraine, e-mail: \\ bbodik14888@gmail.com,ORCID: https://orcid.org/0000-0002-8231-1157
}

\begin{abstract}
The article is devoted to the substantiation of the structural and functional mechanism of the organization of liquidation of consequences of emergencies of medical and biological character. Problematic issues of public administration in emergencies of medical and biological nature, are manifested by analyzing the structure of civil defense of Ukraine and the current regulatory framework governing its activities, as well as the state of government and civil defense forces, which affects their functioning and interaction emergency response time. Civil protection is a function of the state aimed at protecting the population, territories, environment and property from emergencies by preventing such situations, eliminating their consequences and providing assistance to victims in peacetime and in special periods. The developed structural and functional scheme showed that the organizational structure of the system is built on a functional approach, based on the specification of the activities of each structural element at four territorial levels. The functional subsystem at each territorial level has an appropriate organizational model of interaction between government agencies and civil defense forces. Moreover, organizational interaction is coordinated by the internal subsystem - the coordinating bodies, information interaction - the external subsystem of notification, information, monitoring. The study of the current model of organizational interaction between the subjects of liquidation of health consequences of emergencies showed that the dominant principle of its construction is functional, which prioritizes the functional responsibilities of a single body, rather than logical and consistent relationship of work and functions for interacting bodies. In order to establish the content of interaction of elements of the subsystem of prevention and elimination of medical and sanitary consequences of emergencies with other subsystems of the unified state system of civil protection and to develop a draft plan of joint actions of interacting services, the subsystem of prevention and liquidation of medical consequences.
\end{abstract}

Keywords: emergencies, management, mechanism, structural-functional, medical-biological, liquidation.

JEL Classification: H41, H79, I18

Formulas:0; fig.0; tabl. 0; bibl. 11

Introduction. In accordance with the Association Agreement between Ukraine, on the one hand, and the European Union, the European Atomic Energy Community and their Member States, on the other hand, Ukraine has committed itself to protecting human and animal life and health, preventing the spread of dangerous infectious diseases in the country, increasing preparedness in response to outbreaks of infectious diseases. Infectious diseases are one of the most serious threats to modern society, directly and indirectly affecting the quality of life. In modern conditions there is an intensification of the epidemic process and the global spread of new, the return of old and emerging nosological forms of infectious and parasitic diseases. Dynamic growth of cross-border movement of people, goods and vehicles, uncontrolled movement of animals and infected livestock and products, lack of national monitoring of vectors of dangerous infectious diseases against the background of unstable epidemic and epizootic situation in the world, increased risk 
of terrorist attacks and armed conflict import and spread on the territory of the country of pathogens of dangerous infectious and parasitic diseases and the occurrence of related emergencies [1-2].

The risk of medical and biological emergencies caused by infectious diseases of the population in Ukraine is high. The scale of the consequences of medical and biological emergencies caused by infectious diseases makes the organization of public administration in the field of civil protection among the most relevant and important tasks of central and local executive bodies and local governments. Coordination of all branches of government in the elimination of the consequences of medical and biological emergencies caused by infectious diseases requires clear management and coordination of actions to ensure the effectiveness of the whole set of measures. The available experience shows that there is a lack of organization of measures management in overcoming medical and biological emergencies caused by infectious diseases at the national and regional levels. The result is the loss of holistic management of the public administration system, overloading with secondary tasks, the ineffectiveness of existing algorithms of action and approved response plans, loss of time, reduced effectiveness of measures, significant economic losses. Coordination and control of the participation of public and international partners involved in the elimination of medical and biological emergencies caused by infectious diseases is almost non-existent.

Literature review. V. Bakumenko, V. Bogdanovich, V. Vorotin, V. Goshovska, N. Hrytsyak, M. Izha, V. Knyazev, O. Lebedynska, V. Lipkan, P. Nadolishniy, N. Nyzhnyk, V. Oluyko, L. Prykhodchenko, I. Rozputenko, G. Sytnyk, V. Troshchynsky and other scientists. I. Shpylovy studied the improvement of approaches to state regulation in the field of natural and man-caused safety. A. Kaczynski studied the issue of risks in Ukraine taking into account such a factor of instability as emergencies of natural and man-made nature.

Aims. The purpose of the publication is to substantiate the theoretical aspects of the implementation of the structural and functional mechanism of emergency management of medical and biological nature.

Methods. The methodology of this study implies the use comparative analysis, the study of domestic and foreign researches, studying digital transformation processes of the public administration system in Ukraine.

Results. Problems of effective and adequate civil protection of the population affected by emergencies (EM) is one of the urgent tasks of modern health care and medical science, due to two causal factors: first, the increasing frequency and severity of emergencies, and secondly, the emergence of new types of emergencies, in particular socio-political nature, which requires a special nature of the organization of the process of emergency response.

In Ukraine, among the medical and biological threats, the greatest danger is infectious diseases and mass poisoning of people. In the conditions of growing anthropogenic load on the environment, increasing resistance of infectious diseases to chemotherapeutic drugs and disinfectants, diversity of natural zones and biocenoses of Ukraine, creating favorable conditions for long-term existence of natural focal 
infections, detection of new nosological forms. on the territory of the country (Covid19, viral hemorrhagic fevers of Crimea, West Nile), increasing migration, increasing international trade in food, as well as natural disasters and catastrophes, there are objective prerequisites for rapid change in the epidemic situation in some areas countries. Deterioration of the social, economic and environmental situation has affected the level of medical care, the state of immunoprophylaxis, and, accordingly, the level of infectious diseases.

Ukraine joined the COVID-19 pandemic on March 3, 2020, when the first confirmed case of coronavirus $2019-\mathrm{nCoV}$ was reported in a Chernivtsi Oblast resident returning from Italy. Since then, the situation has deteriorated rapidly and as of the end of the 13th week of 2021 registered 1755888 confirmed cases of COVID19 in Ukraine, the incidence rate was 4610.4 per 100 thousand population, including children aged 0-17 years ) 84409 , which amounted to $4.8 \%$ of the total number of cases. The weekly dynamics of registered COVID-19 cases shows their growth. COVID-19 cases are registered in all regions of Ukraine, and the largest number of them was in Kyiv (167668 cases) and Odesa (113735 cases) oblasts [3-4].

During the period of epidemiological surveillance, a total of 34,587 deaths were registered among people with a confirmed diagnosis of COVID-19, including 23 children aged $0-17$, which was $0.1 \%$ of the total number of deaths. The mortality rate was 90.8 per 100,000 population and the mortality rate was $2.0 \%$. The highest mortality rate was registered in Kirovohrad region (3.5\%), and the lowest - in Cherkasy region $(1.3 \%)$.

If the largest number of confirmed cases occurred in the age group from 30 to 69 years $(74.4 \%)$, the death toll was registered mostly among persons over 50 years (93.4\%).

Despite the restrictive measures introduced, the uncontrolled spread of the pathogen in the country is still not overcome, which will certainly have serious consequences for the health of the population and the economy of Ukraine.

Since the beginning of the pandemic, the SARS-CoV-2 virus has changed significantly, acquiring genetic diversity. SARS-CoV-2 mutates much more slowly than other viruses, such as influenza virus or human immunodeficiency virus.

Currently of greatest concern are three mutated strains of SARS-CoV-2 viruses, which are more contagious than other species, among these variants is a virus called VOC 202012/01, first detected in August 2020 in the UK, virus 501Y.V2, first detected in October 2020 in South Africa and the P.1 virus, first detected in December 2020 in Brazil. At present, these viruses have become quite common in some countries and continents, there is a combination of their spread.

Search and rescue of people in disasters and emergencies with a large number of victims (oil leaks and especially dangerous chemicals, isolated cases of terrorist acts) account for $80 \%$ of the total number of cases, so their consequences are eliminated according to pre-developed principles and algorithms.

Management in an emergency is the constant guidance of the governing body and the authorized head for the elimination of emergencies by the services and forces involved and in the organization of the tasks of emergency response or its 
consequences. The main tasks of management are: maintaining a high level of moral and psychological condition of personnel and constant readiness for action; early planning of forces; continuous collection and study of data on the situation in the emergency area; timely decision-making and bringing them to subordinates; organization and provision of continuous interaction; organized collection and evacuation of the population from the emergency zone; preparation of forces and means for carrying out emergency rescue and other urgent works related to emergency response; organization of comprehensive provision of forces and means; control over the timely implementation of measures and tasks by subordinates and provide them with the necessary assistance [5].

Factors influencing the elimination of emergencies include the following: political, economic, institutional, socio-humanitarian, psychological, technological, informational, organizational, spatio-temporal. Political factors reflect the distribution of the main tasks among public authorities at the central and regional levels, namely: the Cabinet of Ministers of Ukraine, ministries and territorial authorities. Economic factors are financing measures to eliminate the consequences of emergencies, compensation for victims, logistics of civil protection measures, which in turn is a set of organizational, engineering, legal and other measures aimed at continuous supply of government and civil defense forces, as well as the population affected by the disaster [6-7].

Under the institutional factor we understand a set of institutions-rules, institutions-organizations and institutional conditions, namely: the formation of the principles of safe living in Ukraine, balanced economic and environmental policy, sustainable use of nature, recreational landscaping, creating effective management bodies to prevent emergencies.

The basic principles of security are the ways of practical application of the achievements of life safety for the sustainable harmonious evolutionary development of man and society.

Socio-humanitarian factor reveals the volunteer movement - information and educational activities, training in skills of home care, improving the training of volunteer rescuers, dog trainers, involving the public in disseminating knowledge about survival in emergencies of various kinds.

The psychological factor is the prevention of panic among the victims, psychological support for the professional activities of rescue teams, and as a mandatory element - medical and psychological rehabilitation of rescuers and personnel of mobile medical teams.

Information factor - the use of modern information and telecommunications technologies to support management decisions, obtaining timely and adequate information about the consequences of emergencies and the situation in the emergency zone, technology OLAP-analysis and spatial analysis by GIS technology in determining the emergency zone, automated monitoring systems and NPPs [8].

The organizational factor reveals the goals and objectives of the Unified State System of Civil Protection (EDCS) as a set of government, forces and means of 
central and local executive bodies, executive bodies of councils, enterprises, institutions and organizations that implement state policy in civil protection.

Spatio-temporal factor - EDTSC operates continuously and continuously throughout Ukraine. Depending on the scale and features of the projected or emerging emergency, one of the following modes of functioning of the unified state system of civil protection is established in Ukraine or within its specific territory: daily functioning; increased readiness; emergency situation; state of emergency.

Summarizing the above, it should be noted that the combination of economic and psychological factors influencing the process of emergency response may be pronounced negative. At the same time, the combination of informational and sociohumanitarian factors allows to optimize management decisions and bring assistance to the victims. Ignoring the importance of political and economic factors, neglecting the problems of adequate funding for civil protection measures both in the period of emergency response and in preventing emergencies, can reduce the level of natural and man-made security of Ukraine [9].

Existing threats of both internal and external nature, probable risks of natural and man-made disasters, emergencies of various levels - determine the constant readiness of the national health system to adequately respond to certain challenges in emergencies, terrorist acts and special periods. . The effectiveness of measures to provide medical care to the population of Ukraine in case of emergency, in a special period depends on the organizational and legal framework defined by law.

In accordance with the Resolution of the Cabinet of Ministers of Ukraine of April 14, 1997 №343, the State Disaster Medicine Service was established, the organizational and methodological guidance of which is provided by the Ministry of Health of Ukraine. Coordination of the Service's activities in case of emergencies is carried out by the central and territorial coordination commissions. The Service consists of medical forces, facilities and treatment and prevention facilities at the central and territorial levels, regardless of departmental affiliation, which must be agreed with the relevant ministries, regional, Kyiv and Sevastopol city state administrations. Thus, the State Disaster Medicine Service is a functionally integrated structure of medical forces and facilities of various departments both at the central level and at the territorial, organizational and methodological management of the Ministry of Health of Ukraine.

The Ministry of Defense of Ukraine is the most powerful of the medical structures of the ministries that are functionally part of the State Disaster Medicine Service. The powers of authorities, rights and responsibilities of other entities are established by the Civil Protection Code of Ukraine, which entered into force on 01.07.2013 [10]. In particular, in ch. 9 - "Medical, biological and psychological protection, ensuring sanitary and epidemiological well-being", in Art. 36, 37 the tasks for public authorities concerning medical and biological protection of the population are defined.

From the first minutes after the emergency, the work of health authorities should be aimed at providing emergency medical care: mobilized medical staff, mobile units of the disaster medicine service were sent to the emergency center, supply of 
medicines and medical equipment, medical evacuation of victims, order on the roads and uninterrupted operation of transport.

In the conditions of mass sanitary losses, which determines the need to distribute the mass of victims, medical sorting is of particular importance, which should provide favorable conditions for the most rational use of qualified medical (especially surgical) forces and adequate involvement of treatment and prevention facilities, most effective and timely medical care. as many victims as possible in the required order.

A functional model of management of medical care in the elimination of medical and sanitary consequences of emergencies with a significant concentration of people is presented. In building the model, we used a systematic approach, which allowed us to logically link the sequence of actions in the management of the process of providing medical care in emergency situations. This author's functional model of management of medical care in the elimination of health consequences of emergencies in large crowds is based on the results of a comprehensive analysis of practical experience in providing medical care by mobile medical formations of the EMD disaster medicine service victims of natural and man-made disasters in Ukraine and and beyond as part of international humanitarian missions.

Discussion. Due to the fact that at the time of the emergency there is a negative impact on the existing management system of health facilities in the affected area, the reliability and completeness of information about the location, nature and consequences of the emergency occurred in the affected area. Information that an emergency has occurred (Urgent notification of an emergency with medical consequences) via UIAS communication channels is transmitted from the territorial center of EMD and MK to the reserve communication node of the Ministry of Health of Ukraine (UNPC EMD and MK). This message contains information about the nature of the emergency, the scale, place and time of the event, as well as information about the dead and injured. When forming this urgent message, there are sometimes discrepancies in the presentation of information about victims and deaths due to the imperfection of the form of urgent message, which does not clearly state that the number of dead is written on a separate line in the text [11].

To date, the problem of preventing emergencies of medical and biological nature caused by infectious diseases of the population in Ukraine, involves the preparation and implementation of a set of legal, socio-economic, political, organizational, technical, sanitary and other measures aimed at risk management, assessment of risk levels, early response to the threat of an emergency based on monitoring, expertise, research and forecasts of possible events in order to prevent them from escalating into an emergency or mitigate its possible consequences.

The interaction of governing bodies in the context of administrative reform, the reform of central executive bodies, which are part of the state system of prevention and response to emergencies is a multifaceted and complex problem.

Solving this problem required the development of a specific research program using a systematic approach, defining the subject and object of research and phased research. As a result of this work, reliable and complete information was provided on each of the tasks. 
Conclusions. Under conditions when the medical consequences of the emergency meet certain criteria and the situation is described as the presence of a significant contingent of victims in need of medical care in the emergency zone, the need for medical care is determined, then the required number, profile and location mobile medical formations in the emergency zone. In the emergency zone, teams of constant readiness and queues of the disaster medicine service and mobile medical points of the civil protection service can be deployed. In parallel with the introduction of search and rescue formations into the emergency zone, the disaster medicine service is being introduced into the zone of mobile medical formations.

At the next stage of the organization of medical care in the elimination of health consequences of emergencies with a large crowd of people is the procedure of medical sorting, which is the main doctrine of disaster medicine and serves to ensure timeliness and adequacy of medical care to victims. Analysis of the factors influencing the elimination of emergencies, political, economic, institutional, sociohumanitarian, psychological, technological, informational, organizational, spatiotemporal showed that:

- a set of economic and psychological factors influencing the process of emergency response may be pronounced negative;

- a combination of informational and socio-humanitarian factors allows to optimize management decisions and bring assistance to the victims;

- ignoring the importance of political and economic factors, neglecting the problems of adequate funding for civil protection measures both in the period of emergency response and in preventing emergencies, can reduce the level of natural and man-made security of Ukraine.

\section{References:}

1. Belousov A.V. The essence, components and content of the complex mechanism of state emergency risk management. URL: http://www.kbuapa.kharkov.ua/e-book/db/2014-2/doc/2/10.pdf

2. Voitovich R.V. (2011). Mechanisms for overcoming the globalization challenges of Ukraine's social development. Bulletin of the National Academy of Public Administration under the President of Ukraine. № 2. pp. 90-98.

3. Lubinsky A. Current state and prospects of modernization of the civil protection system of Ukraine URL: http://www.lvivacademy.com/vidavnitstvo_1/edu_43/fail/15.pdf

4. Melnichenko O.A. (2014). Mechanisms of state emergency management: essence and components. State building. №14. URL: http://www.kbuapa.kharkov.ua/e-book/db/2014-1/doc/2/04. pdf.

5. Poteryaiko S.P. Features of functioning of mechanisms of public administration in the field of civil protection in modern conditions. URL: http://visnyk.academy.gov.ua/pages/dop/77/files/375bed52-fc05-448d900d9ae976544720.pdf.

6. Trush O. Mechanisms for implementing state policy in the field of civil protection. URL: http://www.kbuapa.kharkov.ua/e-book/tpdu/2010-4/doc/5/01.pdf

7. Fedorchak V.V. (2018). State risk management of emergencies: a monograph. Kharkiv: NUTSZU, 305 p.

8. Belousov A.V. (2015). Scientific approaches to determining the risk of emergencies as an object of management. Scientific research on state and municipal administration. № 1. pp. 224-235.

9. An Official Statement made by His Excellency Zbigniew Czech, at the sixth session of the Global Platform for Disaster Risk Reduction, May 2019. PreventionWeb, United Nations, 2019. Available from http://preventionweb.net/go/68455

10. Declaration of France - World Disaster Reduction Reduction Platform (GPDRR) 2019. PreventionWeb, United Nations, 2019. Available from http://preventionweb.net/go/68428

11. Monitoring of the Sendai Framework: An Introduction. Available from: https://www.preventionweb.net/drrframework/sendai-framework-monitor/ 